\title{
Reconstruction of Changes in Banking Regulation Policy to Legal Process and Housing Ministry (Housing Financing Liquidity Facility)
}

\author{
Arum Widiastuti $^{1 *}$, Gunarto ${ }^{2}$, Akhmad Khisni ${ }^{2}$
}

${ }^{1}$ Student of Doctoral Program in Law Studies, Universitas Islam Sultan Agung, Semarang, Indonesia
${ }^{2}$ Lecturer of Doctoral Program in Law Studies, Universitas Islam Sultan Agung, Semarang, Indonesia

DOI: $10.36348 /$ SJHSS.2019.v04i10.004

| Received: 16.10 .2019 | Accepted: 23.10.2019| Published: 30.10.2019

*Corresponding author: Arum Widiastuti

\section{Abstract}

In the Law of the Republic of Indonesia No. 1 of 2011 on housing and residential areas, article 1 item 7 states that a house is a building that serves as a decent residence, a means of family building, a reflection of its owner's dignity, and assets to its owners. In order to provide facilities and / or assistance in obtaining access to homeownership credit to lowincome communities, In 2010, the government through the Ministry of Public Housing issued policies and strategies through the Housing Financing Liquidity Facility (FLPP). The FLPP policy is a solution for the Low Income Community (MBR) to have affordable housing right away. In order to address these issues some policies are needed in order to achieve the country's objectives. That is the reason why researchers have taken this issue as a research in this dissertation. While the formulation of the problem is (1) Why is the policy of banking regulation of the legal process and housing service (Housing Financing Liquidity Facility) not yet fair? (2) What are the weaknesses of the current regulation of banking regulation of FLPP (Housing Financing Liquidity Facility) legal process and services? (3) How is the regulation of the banking regulation of the legal process and the servicing of the FLPP (Housing Financing Liquidity Facility) based on fair value? In connection with the title of this research, this study aims to present or exploit and analyze the reconstruction of regulatory policies aimed at fair value-based FLPP housing. This analytical descriptive is to illustrate a legal situation as it is with the theoretical paradigm of constructivism, and then explain it in a logical, systematic and comprehensive discussion. The research approach using empirical norms is selected by researching library materials or secondary data only. The results of this study conclude that (1) To support the creation of a fair financing market, access to long-term funding is required. The long-term availability of funds will depend on whether or not the housing financing system works. (2) Available mortgages consist of conventional mortgages and subsidized mortgages, both of which are channeled through banking. Because banks have restrictions on lending that do not match the source profile of the banking fund, then some societies that do not meet banking requirements for conventional and subsidized mortgages belong to the marginalized group. (3) A more equitable housing financing system will encourage the market to be more fair, and the procedure for owning a home will be simpler and the prices will be more affordable. Using MBR interest rate theory can afford a home by paying low interest rates until repayment.

Keywords: Reconstruction, Banking Regulatory Policy, Law, FLPP Housing Services.

Copyright @ 2019: This is an open-access article distributed under the terms of the Creative Commons Attribution license which permits unrestricted use, distribution, and reproduction in any medium for non-commercial use (NonCommercial, or CC-BY-NC) provided the original author and source are credited.

\section{INTRODUCTION}

Indonesian banking has been on the rise and decline over a period of two decades following the strengthening of market mechanisms in the Indonesian banking sector. After that, national banking began to boom in the eighties. The phenomenon of flooding Indonesia's banks is not accompanied by careful regulation and management of bank funds in an attempt to reduce and anticipate relatively high banking risks. Regulation has also emerged as a reactive effort to the crisis or the current banking situation, particularly in terms of its impact on the national economy and for the benefit of the people who are invested in national banking.

Indonesia's banking regulations are the keepers of the Indonesian banking system which is already part of the global financial system. These regulations are generally reflected in the various rules of the Central Bank of Indonesia following the circular which is constantly updated or modified in accordance with the conditions and situation of the national banking. Significant regulatory changes usually occur in times of crisis or worse situation. The series of significant 
regulatory changes is often known as the Central Bank of Indonesia's policy package.

Central Bank of Indonesia has the authority to implement monetary policy by setting monetary goals with a view to inflationary targets. Inflation is a situation in which the amount of money circulating exceeds the amount of money needed for the economic course of a country. This is marked by a decline in the value of the currency of the country and followed by a general increase in prices of goods over a period of time.

Banking regulations in Indonesia are implemented through the regulation of Banking Law which is the Law No. 7 of 1992 on banking as amended by Law No. 10 of 1998 and the Law No. 23 of 1999 on Central Bank of Indonesia as amended by Law No. 3, 2004. With the aim of protecting the banking industry against risk, which in turn means protecting customers and the economy from failures of processes and procedures that could impact the financial system as a whole. Some considerations on why regulation is needed for banking: Debt to capital ratio; Capital; Insolvency; The role of the Central Bank as lender of the last resort; Stability of finance; Monetary stability; Liberalization of international finance; International competition and financial product innovation.

Indonesia as part of the global economy has not survived the global financial crisis. As a country that has signed free trade treaties, Indonesia has become one of the key points in international transactions, all of which require banking roles and functions. The greater the value or volume of international transactions involving a bank, the higher the risk facing the bank. If one of the key chains is failing, then such a domino effect of the financial failure of overseas banks will slow down to Indonesia. Regardless of the extent of national banking dependence on such international transactions, Indonesia, in particular Bank Indonesia, needs to anticipate from the event of a financial crisis or banking failure in other countries.

The dynamic growth of banking demanded Bank Indonesia's role in monitoring national banking performance. The development of increasingly complex and integrated banking products and services in the global economy has required Bank Indonesia to continuously regulate and monitor banking, maintain a payment system, and conduct monetary equities in keeping with the evolving national banking situation and direction. The existence of the Indonesian Banking Architecture in 2004 is one of the strategic efforts of Bank Indonesia in strengthening national banking in the future, including adopting various regulations that were boiled and introduced by Bank for International Setlement (BIS).
Bank Indonesia as the Central Bank performs its duties and authority in accordance with Law No. 23 of 1999 concerning Bank Indonesia on May 17, 1999 as amended by Law of the Republic of Indonesia. 6, 2009. In a general explanation of the law it mentioned the impact of the global financial crisis on countries including Indonesia, as the global financial system interdependently.

\section{Why is the policy of banking regulation of legal process and housing service (housing financing liquidity facility) not yet justified? \\ As part of the international community,} Indonesia also signed The Millennium Development Goals, which set a target of increasing the livelihood of 100 million people by 2020 [1]. The rise in house prices as compared to the rise in income and the high rate of interest on Home Ownership Credit (Mortgage) rates has hindered the realization of these ambitions. The gap in home ownership creates a slum of residential neighborhoods around big cities, which visually reflects the inability of a country's housing finance system, as Renaud [2] says, "Cities are built the way they are financed". Lack of housing and high poverty rates reflect low per capita income. Housing problems in developing countries are generally not the Government's priority, as Steedman said in Satyanarayana's "Of the fundamental human needs, housing has traditionally ranked lowest in the priority of most developing countries" [3].

Housing is one of the basic human needs, but the housing financing market in Indonesia is still lagging behind due to relatively slow growth over the years. The results of the UN-Habitat study show that the housing finance market in Indonesia has not been functioning effectively \& efficiently. Inefficient markets mean that the housing financing system is unable to provide the long-term funding needed by the housing financing sector. Long-term funds are likely to result in limited mortgage lending. Historical data shows that the long-term funds of the Indonesia Retirement and Insurance Funds in Indonesia are scarce, but a significant amount of these funds are placed on deposits and State Debt (SUN).

Thus, one side of the banking system needs long-term funds to finance long-term, long-term, longterm, financially viable mortgages that are better directed at SUNs and deposits. The findings from the UN-Habitat study and the authors' observations indicate the following: (a). The financial sector is dominated by banking and only a small portion of the banks provide mortgage facilities. The Bank generally does not serve the lower middle income community segment, except BTN Bank. In the meantime, the participation of the Financing Company is relatively limited, as the mortgage volume is relatively small compared to other developing countries; (b). in certain periods, some of the Banks lend their mortgages at a lower rate than the 
market rate, for the first 1 or 2 years, after which time the Bank reserves the right to impose a new rate, without limitation. The mortgage loan with tieser rate will be a problem when the ability to install is calculated based on the magnitude of the first 2 years of low installment at the time the bonder rate expires, and turns into an adjustable rate mortgage (ARM), the amount of the installment obligation will increase which will affect the ability of the next installment. In addition, some Banks offer top-up credit (equity withdrawl) that can be used for a variety of purposes, including consumer needs; (c). Credit agreements are possible, even if the home is not ready for pre-sale. Since valuation is not possible then the developer's selling price, however large, is used as a benchmark to calculate the maximum mortgage; (d). Mortgages are offered at floating rate rates, except for Government program loans, so consumers will face credit risk as they continue to pay larger mortgage installments if market rates rise. (e). Usually a mortgage application is filed through the developer. The UN-Habitat recommendation is for the Government to set policies that encourage efficiency [4].

Compared to the mortgage lending practices of the 1990s, there are significant differences. The mortgage can then be provided at a constant interest rate for the first 3 to 5 years. Also, credit is only made after the home is ready. This is possible because construction credits are available so developers can sell ready-made homes. In this way, the fairness of the sale price and the value of the home to be collateral can be measured. A home equity valuation is very important for the Bank to ensure the security of its investment as well as for consumers as the justification for the sale price is measured. The way pre-sale arises from getting construction credit for developers is not as easy as it was before the crisis of indigenous mortgage practice until now. Housing financing in the United States. before 1970, the United States experienced a fluctuation in the flow of funds needed for housing financing, thus limiting the opportunity for leveraging available longterm funds. This situation was exacerbated by interest rate policies that distorted the flow of funds to the housing finance market and eventually contributed to the crisis in 1930. The deregulation issued post-crisis 1930 [5] has a key message in the development of the Secondary Mortgage Market (SMM). To ensure the continued availability of long-term funds to expand home ownership especially for low-income earners, as well as to expand the financial markets, particularly the capital and SME markets, the United States Government has issued various deregulation policies including the following: (1) Introducing a Home Loan Bank (HLB) system that serves as a liquidity facility, with the task of lending to a mortgage lending institution that is a member of the bond issuing fund. (2) Introducing the Federal Housing Administration (FHA) and the Veterans Administration (VA), which is a Government guarantee program to increase MBR affordability to relieve Mortgages and protect mortgage lenders from credit risk. (3) Introducing the long-term amortized fixed rate mortgages and short-term non amortizing mortgages known before 1930, to make them more affordable. This method is then used worldwide. (4) The Federal National Mortgage Association (Fannie Mae) was established to maintain the stabilization of the mortgage financing market, with cars buying mortgage loans at a time of rising demand, and selling at a declining market rate [6]. (5) Introduce and apply the standard use of mortgage documents to support SMM development. The documentary standards that were later developed in many developing countries of Asia, were an indispensable part of the development of securitization document standards also serve to protect consumers against unhealthy practices [7].

The Indonesian government is of the view that with the help of SMMs, long-term funding will be available, which is expected to solve the maturity mismatch problem and gradually encourage the creation of a more affordable interest rate climate. Based on that thinking, in 1993 the Minister of Finance formed a working group to study possible SMM development in, Indonesia. The study obtained a barman from the United States Agency for International Development (USAID) with lead expert Michael Lea. Lea concludes that Indonesia is not ready to develop SMM [8]. Lea's recommendation is for the Government to set up a liquidity institution that acts as a liquidity facility that issues corporate bonds and proceeds as a loan to banks. The Government is also advised to provide guarantees in the form of the Minister of Finance's ability to provide obligations issued by the liquidity facility. The existence of these guarantees enables the institution to obtain the highest credit rating and thus enhances investor confidence in newly introduced bonds [9]. As such, the institution is able to accumulate large amounts of long-term funds lower than without guarantee guarantees, thus meeting the need for more affordable mortgage and reaching more investors as Cagamar Berhad [10]. The growth of these institutions could drive the creation of a more efficient housing financing sector that could serve as a platform for SMM development in the future.

If housing financing in a country can be managed well, it can build a stable pillar for the entire financial sector [11]. In addition, if the Government wants to facilitate the provision of housing to the public, then the Government should provide for the development of securities by providing the necessary regulatory framework and release various barriers to accessing capital market funds and mortgage loans. However, encouraging mortgage growth, it should be supported by the availability of well-functioning and efficient housing financing. Excessive mortgage growth, surrounded by inefficient and backward housing financing systems, are vulnerable to speculative attacks. If not managed properly, it can 
trigger the formation of property bubbles that will endanger the financial and economic markets.

To ensure the long-term availability of funds, the Government has chosen to expand SMM. Introducing a new system should be followed by providing a regulatory framework. Governments need to make sure that the system they choose is working properly. Introducing a new system that is not supported by adequate regulation may result in the system not functioning properly, which impedes accessibility to capital market funds and may jeopardize the future growth of the housing financing market. Continued failure can negatively impact economic growth. The absence of a regulatory framework to support the development of SMMs, which is already the Government's choice, is a failure. Increased access to funding to the capital market as well as the public's ability to own a home can only be achieved if the SMM formation goes well so that securitization is ongoing with increasing transaction value. The ongoing issuance of RMBS can also boost investor confidence and could lower the cost of funds, thus leading to the formation of market mechanisms that can create a more affordable mortgage rate climate [12].

Housing financing system. One of the key features of mortgage is its long-term nature, and the amount of funds needed is relatively large given the relatively high cost of housing compared to other household spending. Therefore, in order to facilitate housing needs for the community a large number of long-term financing sources are needed. The purpose of the short-term housing financing system is to provide the people with the funding needed to buy a home. The functioning of this system will involve various agencies. All of these activities are intended to flow funds from the beneficiaries to the needy with efficient and effective funds. A well-functioning home financing system can drive the formation of a healthy and efficient country financial system and contribute positively to economic growth.

In countries where the housing financing system is not functioning well, housing needs are often informally addressed, especially by people who do not meet the banking requirements for conventional and subsidized mortgage mortgages. One way to deal with this is to build your own house gradually over the years with your own funds and family assistance or through cooperative loans. Also, for those who are more capable, it is usually a gradual purchase through a developer, like a mortgage. The same way it is often a choice for consumers who refuse to get involved with the bank. Such methods of buying are obviously inefficient and relatively expensive and pose a risk to consumers as they are not a fluctuating benchmark for ads or for a clear basil. The most common way for many countries to facilitate their funding needs for housing is to open up opportunities for the various types of financial institutions that provide mortgage loans to reach more MBRs. These institutions can be public or private or mixed companies.

The availability of funding for housing depends on whether or not the housing financing system works. In order for these systems to function properly there is a need for adequate regulatory frameworks that enable the efficient financing of the housing market. The legal framework should include the sale of bills, and the establishment of an SPV business body, for the instrument to be published in a more efficient and cost-effective manner. Government support is needed to open up the demand for long-term sources of funding from the capital market, as developing a housing financing system is an indispensable part of the economic and financial sectors [13].

The main purpose of Government housing policy in every country is to facilitate affordable and affordable housing for all sectors of society. For certain groups of people who are discriminated against by the market for not being able to reach formal funding, Government intervention is required, usually through various subsidy programs. Subsidies programs that have been around for a long time, are usually designed by the ruling Government, to be modified by the next regime, as a result of previous programs not being continued, though at times the programs are quite good and running smoothly.

There are still many weaknesses in the housing financing system that must be addressed before it can reach lower market segments, such as high interest rates, partly due to lack of credit information and credit risk management mechanisms. UN- Habitat. Therefore, the Government's commitment to address the lack of housing for MBRs should begin with facilitating the development of a strong and efficient national housing financing system. International experience has shown that setting a housing financing policy for a country's MBR cannot be detached from the context of the overall housing financing market, even if handled separately [2]. In developing countries where the housing financing market is already distorted, there will be difficulties in addressing the housing demand for MBRs, as the housing financing system has failed in facilitating housing for the middle-income community. [14]. As long as the system has not been able to meet the housing needs of the middle-income communitybecause the system is not efficient so it is not workingit is difficult to believe that the problem of housing financing for MBRs can be solved. This may be why housing backlogs are difficult to overcome so they tend to be chronic issues. Prolonged backlog issues can result in heavy Government burdens including overcoming the social costs incurred by the backlog. 
The Government's attempt to facilitate the provision of housing by physically building the residence is a short-term solution. In the long run, this solution is inadequate to implement, other than expensive, and inefficient as the cause of the problem arises, but remains untouched [15]. Government intervention often increases poverty levels. Government programs tend to cause the public to rely on Government assistance and to impede the independence of the community [16]. Countries that want to facilitate long-term housing provision should be able to address the root causes of the shortage of habitats that typically range from: Climate not conducive to mortgage growth including lack of regulation; Inefficient housing financing market. Long-term funds available, inaccessible; The emerging market of corporate bonds is dominated by banking; Macroeconomic conditions are poorly supported.

Today, the Central Government promotes subsidized mortgage lending for MBRs (mortgages) through banking. Over the years, various subsidy programs have been implemented, while the peace process has changed, the program has changed. The reason for subsidies is always around high interest rates, but the reason for the high interest rates is that they are losing their attention.

If the subsidy feature makes the mortgage unsecured, then the bank has to keep the mortgage under wraps, while there is a limit to keeping the mortgage on the balance sheet for the long term because the mortgage involves a variety of risks and limits the Bank's ability for other credit extensions. So not many banks are interested in lending their MBRs. Such subsidies are shortcuts that are relatively easy to design, yet difficult to implement and potentially cause market distortions. Provides non-securities subsidy programs, plus PT. SMFs that are not working at all are two inefficient programs. This may be due to a lack of understanding of the housing financing system and poor coordination between agencies regarding housing financing. If the mortgage-MBR can be securitized, and if the PT. SMFs have the highest credit rating, so the subsidy program can gradually be reduced by decreasing market interest rates as a result of ongoing securitization transactions.

Conventional mortgage-MBR and mortgage programs, both by banking. For groups of people who do not qualify for banking, it is possible to obtain a conventional mortgage at market rate, or a mortgage with a subsidy, a marginalized group. The best international experience shows that the Government of a country usually provides the Specialized Non-Bank Financial Institution (NBFI-Special) to address this problem (NBFI). NBFI-Special extends credit to specific groups of people (generally non-bankable), in certain sectors of the economy (including the housing sector) [17]. However, similar institutions have not been recognized in Indonesia since 1992. As a result, these groups must meet human needs by building technologically and humanely, inadequate homes. In the end, the two programs above expanded the slums and increased poverty, which required cost overruns. How ironic the dynamics of housing finance are in Indonesia.

The research in compiling this book was conducted using the approach of Economic Law (Business Law) introduced by Posner, which applied economic principles as a rational choice to analyze legal issues [18]. Posner's theory is essentially efficiency. Efficiency is the moral and central point of the normative Economic Law [19]. On the other hand, hockey should be designed to provide social satisfaction, a satisfaction measured by individual judgment because the individual is in the best position to determine one's well-being [20]. Through the approach of Economic Law, economic principles are used to explain the impact of a law on society, predicting what will be most efficient, and predicting how regulations should be enforced [21]. To this end, economic theory and empirical methods are applied to the legal system as a whole. Law and economics should be viewed as one unit in a social system. Law and the economy is a system that contains the values that live in society. Both disciplines, part of the social sciences, seek to understand human behaviorals. Economists need to understand various aspects of law that are qualitative and on the contrary, they must also understand quantitative economic theory and be able to translate it into legal and social aspects. Therefore, the study of hockey in an economic perspective can be used to provide feedback to the country on laws that are efficient, effective and beneficial to the well-being of society.

The purpose of this book is to analyze the obstacles faced in the development of the housing financing system and to obtain relevant policy implications. The suggested steps will focus on the development of an efficient housing financing system. This book is organized into 5 sections, the first section, which introduces the conditions and issues of housing financing in Indonesia broadly. The second part outlines the efficient and functioning housing financing system by highlighting three key characteristics: The efficient primary housing market. Accessible capital market funds. A strong financial system. The third section presents the profitability of the housing financing system with three main obstacles to developing a housing financing system in Indonesia namely: Climate for uncontrolled mortgage growth, Financial markets have not been well diversified; Macroeconomic conditions have not been fully stabilized. The fourth section presents several initiatives for change to achieve a more efficient housing financing system. Now, the fifth part is the cover. 
This book is based on qualitative, normative, comparative jurisprudential research and considering the cost and benefits aspects so that with limited resources, the Government can greatly increase the well-being of the people. Analyzes were conducted on the housing market conditions, capital markets and macroeconomic conditions needed to develop the housing financing market, while comparative analyzes were conducted on various methods and approaches and approaches to the development of the housing financing market, to identify benefits and costs. Further, comparative qualitative analysis was performed on the regulation and institutional framework of the housing financing market in countries.

Real estate financing covers a wide range of aspects, including real estate, taxation. The author does not have the capacity to cover all aspects of housing financing in this book. Therefore, it is hoped that this study can serve as a catalyst for further research and thus provide comprehensive research results. In addition to the opinions or reasons set forth above, there are other factors that may make it difficult for the regulation of banking regulation of the legal process and FLPP housing service to be unjustified, including the following:

\section{No Regulatory Infrastructure Yet}

The term infrastructure refers to the environment in which transactions in the housing financing sector are carried out in an efficient manner, including macroeconomic conditions, regulatory and institutional frameworks. One of the main goals of the regulatory and supervisory framework in the financial sector is to ensure that the financial system works well in mobilizing funds to support commercial activity financing. In addition, it enhances the effectiveness of the financial system in order to absorb the turmoil and maintain the stability of the financial system [22]. Supporting regulatory frameworks, providing investor protection and providing a marketplace for marketers to be flexible. Supportive regulation, will strengthen the market infrastructure and contribute to the support of the judiciary more effectively, while facilitating the availability of high quality information [23]. Supportive regulations contain elements to monitor market activity to maintain financial stability and encourage healthy practices [24]. In the case of securities, a supportive regulatory framework is one that can strengthen market infrastructure and promote investor protection and support efficient and cost-effective transactions. The underlying principles should include increased transparency as well as increased corporate governance and recognition of regulator accountability. The regulatory framework must be able to maintain a variety of legal relationships in order for the securitization process to operate efficiently. In developing securities, there should be regulations that support the efficient sale of bills and the implementation of efficient securities transactions that include the principles of securities laws and regulations that enable the establishment of special purpose vehicle (SPV) entities that facilitate cost-effective transactions. The transfer of the bank from the originator to the SPV must be done properly. In one jurisdiction, a charge transfer can be done in many ways, for example: cessie, novation or subrogation. Each method selected has definitions and procedures and legal requirements attached to each method, which are different. From the point of view of securitization, the aim is to make the transition possible, the requirements are not so heavy and it is a true sale and it provides legal protection for SPVs and investors as well as protection against billing that is the basis for issuing effects. In the case of a charge transfer, the legal aspects to consider are the nature of the charge, the formalities to be completed to complete the transfer, notification to the debtor (if necessary) of the sale of the creditors and the consequences of not being notified. The regulatory framework must be well-positioned in the legal hierarchy to achieve legal certainty for the benefit of the parties including investors as well as the public. The regulatory framework must contain the principles of law that are fundamental to cross-border securitization [12]. Securities held under regulations that do not comply with international standards can only access domestic funds as foreign investors must test compliance with cross-country transaction standards to ensure safe and profitable investment.

Regulation for securitization should take precedence over achieving social goals of increasing home ownership. This is in line with Oliver Wendell Holmes's view that legal reasoning is not only limited to logic, but also the social purpose to be achieved, and the consequences of working with it. Therefore, securitization must be efficient. Efficiencies in the securitization process are mainly: (a) Consequences for Banks to securitize are to isolate some of the functions of the mortgage process and pass it on to other experts in their field, thus not performing their entire functions on the mortgage lending process [25]. (b) Developing securities should be supported by regulation, Without adequate regulation, inefficient transactions can have a negative impact on economic stability [26].

In the case of securities, in order to meet the minimum operational requirements, the Bank must sell financial assets that meet legal and accounting requirements for the true sale principle to be met. The break-up characteristics include the following elements: (a) the transfer of assets is made so that the assets are legally separate from the Bank's assets and these transfers are legally supported; (b). SPVs that purchase assets and manage asset benefits for the benefit of investors, have the right to guarantee and or exchange the assets; (c). Banks that already sell credit lending have no direct control over their assets as long as the assets have not been sold. If this requirement is not met, then the separation of assets even if the principle of 
resignation is in accordance with local law. Accordingly, the Government's efforts should focus on providing the legal infrastructure necessary to meet the minimum operational requirements in line with international standards relating to the securitization and sale of the Bank's financial assets [27].

Governments that provide opportunities for operating the mortgage market, should allow the market to function properly and efficiently through regulatory and supervisory support. Typically, in developing countries, existing regulations have not yet regulated mortgage debt sales transactions to SPVs with remote bankruptcy status, and regulatory reform efforts should be focused on that. To obtain remote bankruptcy status, the scope of SPV activity should be restricted, only to buy mortgage debt and issue pay-through bonds. The purpose is to prevent lenders, other than the impacted investors, from filing claims against SPVs that allow the SPV to go bankrupt. The jurisdictions of some countries allow the formation of SPVs, some regulate SPVs under the Trust law, while others govern the Company's laws. Wherever the SPV rules are put in place, the most important securities transactions should be able to be implemented quickly, efficiently, and cost-effective especially since securitization is essentially the ability to access cheap long-term funds [28]. The capital market-based transaction model becomes unattractive if there is no regulation that allows lenders to obtain long-term financing while protecting investors from risk. Therefore, regulatory reforms should be aimed at improving the functioning of the market and not burdening the costs which ultimately result in unattractive transactions that limit credit availability, and in turn restrict the public to owning a home. Every regulation that, issued in relation to housing financing, should benefit and not vice versa. The risk is very high if regulatory reform is done by ignoring long-term mortgage features and not considering the need to have an efficient housing financing system. Moreover, the preparation of the regulations is carried out without careful consideration of the causes of the crisis in the past [29].

Effective oversight and regulatory systems are essential for financial market fluctuations. Experience across countries offers three insights to design a surveillance system: (a) The process of regulatory preparation must be efficient. Time is very important for both investors and securities in the securities market. The delayed regulation may cause the market to lose momentum and make transactions more expensive. (b) Taxes charged on transactions and withholding taxes are often the cause of the issuance of securities and trade activities to be performed abroad. (c) Determination of terms such as coupons, timeframe, time of issue and price calculations, is best determined by the investment bank. Rules on issuance of securities should take into account the principle of equality for all market players. Determination of services, should be regulated competitively by regulators. Regulators need to be aware that imperfect competition in the financial industry can interfere with market forces, just as regulatory systems do not work [30].

A strong constitution and a well-functioning regulatory framework are essential for the development of the mortgage-based effects market as it includes a foundation for the protection of investor rights including ensuring that investors will receive a full return on their investment. The study found that countries with regulatory frameworks that provide adequate protection for investors tend to have a deeper capital market. While La Porta and his colleagues are in. Laeven found that during the period 1980-2000, common law countries tended to provide more protection for investors and these countries generally had a stronger and more stable capital market [31].

\section{The securities regulatory framework is not yet available.}

The drafting of the regulatory framework for mortgage securities, should be done with consideration of the purpose of the housing financing system to provide long-term funding. It should also take into account the features of long-term housing credit and the characteristics of real estate financing that do not miss the impact of real estate business cycles. Regulation should be done by carefully studying the causes of past crises. In a stable financial market, investors rely on a comprehensive, stable, fair, and Justified legal and regulatory system as the basis for making investment decisions. if such regulation is not available, it will hinder the development of the mortgage-based effects market as well as other effect markets [29].

Some developing countries in Asia have introduced securitization transactions by relying only on existing regulations while regulating only a few important aspects of securitization. Securitization, which is based on widespread regulation, while costly, also opens up the possibility of protests that may push the market's confidence in the concept of securitization that could ultimately undermine market development. securitization. The hierarchy of low levels, and widespread, produces a long, expensive process, so it does not conform to the essence of securitization, which is efficiency. Therefore, there must be a specially designed legal framework. for securitization [32]. In the primary mortgage financing market, it is necessary to ensure that the regulations regarding mortgage foreclosure are well-structured. Then, in the secondary market should be clear arrangements for the sale of loans to the SPV and clearly specify the terms of recourse or non-recourse. The goal is for marketers to evaluate their transaction structure. In regulation there is a need to distinguish between types of securities, paythrough or pass-through structures [33]. 
In order to provide legal certainty to the transactions and to protect the interests of investors and to build market confidence, a legal regulatory framework must be provided. Regulations that are not designed specifically and that do not conform to international standards make it difficult to gain market confidence and access only domestic funds, as compliance with cross-country standards is still to be tested. Securitization is essentially efficient because it requires the breakdown of functions and allocation of risk to the expert in managing the risk [34]. Securitization is not a means of mitigating risk, but rather of relocating risk. If not done right, it can transfer the risk to those who are not in a position to manage it [14].

The key to economic efficiency, both for the individual and for society, is knowledge. The extent to which an individual acts efficiently will be determined by the amount of knowledge he or she has and the right way to achieve the desired goal. The efficiency for the market as a whole depends on the individual's knowledge of market conditions. In a market economy, voluntary exchanges are mutually beneficial, allowing individuals to simultaneously pursue their goals. The key to efficient pursuit is coordination between buyers and sellers. This co-ordination reflects the extent to which participants are aware of the market opportunities they have.

In an economic system, marketers need to have knowledge of market opportunities and an understanding of how to exploit those opportunities [35].

In an effort to develop a secondary housing financing market, the Government should provide a legal framework to facilitate the issuance of RMBS and make adjustments to existing regulations, as the parties require legal assurance of the transaction. In addition, improper securities are not sustainable and do not provide economic growth. Legal certainty and market trust are critical to the ongoing implementation of transactions. For legal certainty, the regulatory framework must include the fundamental principles of cross-border securities law: transferability, true sale, bankruptcy remotness and perfection of security interest.

The principle of transferablity law relates to the existence of a legal certainty that a mortgage loan and the rights attached to the loan are transferable. In the transfer of assets, it must be ensured that the asset transfer is effective so that it avoids the possibility of claims from other creditors, in addition to the effect buyer lender, including its affiliates. There is a need to ensure that the securitized mortgage debt is separate from the originator's financial assets. The legal system should enable the transfer of ownership of the debt to the SPV with minimal administrative logistical obligations. More logging obligations can increase transaction costs. Therefore, the procedure and the weight of the logs should be designed.secondly as efficient as possible. If there are various administrative requirements to be met, then the possibility of switching to the SPV becomes less effective as there may be unfulfilled requirements [24]. In practice, some countries have ruled that debt transfer can be done without the prior consent of a mortgage debtor [36]. However, there are some countries that specify that for every loan transfer there should be a notice to the mortgage lender. In such a situation, the debtor has the right to cancel the debt transfer if he or she receives no notice, and if this happens it will complicate the execution of the transaction and increase the cost of the securitization process [37].

The next aspect of the law is true sale. The sale of the bill by true sale means the bill is completely out of the originator's balance sheet so it is not part of its bankruptcy [38]. The way in which financial assets are sold is in accordance with the laws of their respective countries, either through novation or subrogation or cessie [28]. The principle of foreclosure implies that the mortgage debt must be sold off by the originator, either from a legal or accounting perspective [39]. With the sales going down, then. The mortgage debt sold is really out of the way. originator assets. The principle of resignation is very important in ensuring that there is no dispute or interpretation that would question the validity of the transfer of ownership of the debtor [40]. Dvorak describes the true sale as follows: "A true sale is a sale that severs the legal and beneficial interests of an asset and is sufficient under bankruptcy law to remove the receivables from the originator's bankruptcy estate. The true sale requirement aims to protect the interest of investors to always receive principal and interest payments, even if the originator is bankrupt. In addition to cost efficiency as the source of payment to investors is structurally separate from the risks that the originator may face, so there is no cost to monitor the originator's financial ability [41]. To determine whether a transaction is a true sale or a loan, at the time of sale, the terms of sale must be met. Importantly, the sale does not create a financial obligation that must still be fulfilled by the originator after the transaction, such as the sale being made on a condition of repurchase. To ensure this, the role of SPV is needed [24]. The characteristics of true sale are: (a) The transfer of financial assets is completely isolated from the originator's assets supported by public opinion. (b) The SPV has the right to guarantee or transfer the benefit to the financial assets. (c) The Originator does not have any direct control over the assets so that the sale is not classified as a loan, although local law still classifies the sale. (Basel Committee on Banking Supervision,) Thus, there must be a legal infrastructure that includes minimum international standards for securities [27]. 
The next principle of law is protection against the impact of bankruptcy remoteness. With the sale of mortgage assets in the form of mortgage loans to the SPV, the assets are completely separate from the originator's assets and are not included in the bankruptcy trustee [42]. In order to protect the interests of investors, the structure of the transactions is designed such that investors are protected from the impact of the bankruptcy of the parties involved in the transaction. Therefore. therefore, SPVs that issue pay-through bonds must be independent entities not affiliated with or owned by the originator. There should be protection in the interest of investors that the assets collateralized by the effect of the SPV issued, avoiding the reach of other lenders other than the buyers of the SPV mortgage bond lenders as a means of isolating financial assets, have begun to develop in several developing countries [10].

Further the principle of protection of investor interest is the perfection ofsecurity interest. Financial assets that have been sold off by the originator, are processed through a transaction structure in such a way that in the event of a failure to pay, the obligation to the investor can still be met with the basis of the execution of the collateral. As such, investors' interests will be protected. There is protection for investors so that their securitized financial assets are exempt from possible claims from their originator lenders. In addition, the SPV should have a favorable legal position over other lenders [43]. The existing legal system should open up opportunities for transferring mortgage loan benefit to investors. What is important for investors is how far the investor claims against, the collateral can be exercised if the debtor experiences a failure to pay. This will depend on the extent to which the status of the land and the rights of the lender are well understood and the ability to execute collateral at reasonable cost and time [33]. Regulations on executing executions should be enforceable to provide investor certainty. Efficient and efficient execution of collateral guarantees is an incentive for investors to invest in mortgage debt pads. The principle of perfection of debt relocation relates to the registering of land rights and rights of collateral which must be made on time and at a reasonable cost. measurable. If the collateral execution process is complicated, confusing and expensive, as well as the perfection of the debt transfer, including unsecured investor reference rights then mortgage debt is no different than unsecured bonds [10].

Recent developments in the global financial markets have shown significant growth. The regulation and oversight of the housing financing sector has led to the utilization of funding from the capital market through securitization transactions. Although. transformations in the financial sector have been carried out by many developing countries, but the growth of the financial markets has been uneven, but still there are differences, especially in the speed of the process of evolution. This has led to some countries experiencing faster growth, while other countries are still lagging behind [12]. Many credit restrictions have been made lighter as Governments of several countries have reexamined the legal framework in which their financial institutions operate. In the past, regulations in the financial services industry, tended to focus on transaction security, consumer protection and failure prevention. Liberalization and deregulation in the financial sector have removed many obstacles by shifting the era of rigid regulation and strict oversight to increased efficiency through market discipline, surveillance and risk management. At the same time, liberalization and globalization have made the capital market more fluid and efficient, thus facilitating the shift from a dependency on the banking system to a market-based system. This shift is further strengthened with the implementation of Basel II, which provides a more transparent and market-oriented regulatory framework. This tendency is further exacerbated by the growth of the secondary market in more developed bond markets [44]. In countries where the bond market is still behind, securitization can be an incentive to encourage transparency and growth in the bond market.

The tax treatment of securitization transactions will determine whether securitization can be done efficiently and cost-effectively. If tax evasion results in inefficient transactions, resulting in relatively inexpensive funds from the capital market, securities transactions are no different from other financial transactions so they are not useful to increase the public's ability to buy a home and are also ineffective in saving the Government budget used for subsidies. Taxation can arise at several stages in a series of securities transactions including taxation on, SPV. Will the SPV be treated as a general body of business or can it be classified as a separate body of business either legally or legally from the parties involved in the transaction? Some countries handle this specifically. For example in the United States, according to the U.S. The Tax Reform Act of 1986 or REMIC (Real Estate Mortgage Investment Conduit) and was later enacted in 1996 for the formation of Financial Asset Securitization Investment Trusts (FASITs) so that trusts could be formed to facilitate securities transactions and issue various classes of securities without taxation, except taxes to beneficiaries. Then another important point is how do taxes on the originator's financial assets be taxed to the SPV? Taxes are usually affected by the type of transaction, whether the transaction is classified as a sale or loan. It is therefore essential to determine whether the benefits and risks associated with the ownership of the financial assets sold, have effectively turned to the SPV [28].

In the case of mortgage debt securities, SPVs are generally trust-based and trustees have a duty to perform in the interests of beneficiaries [45]. No securitization transaction will occur, without the ability 
to form an SPV Investor is not interested in absorbing, the risks attached to the originator. Investors are only willing to take certain risks from a set of contracted financial assets, and the effect is purchased by investors. In other words, the SPV protects investors from bankruptcy or other events that the seller may face. The SPV went into bankruptcy remotely because it was isolated from the sponsoring company and was not allowed to carry out the financial obligations of the bank. SPVs are responsible for securing certain financial assets and issuing and selling effects through market mechanisms. Once established, the SPV must operate as a fully independent entity. Once an asset is sold then the asset is legally isolated and its consequences cannot be reached by the originator including its lender. The financial assets held by the SPV can only be used for the benefit of the beneficiary. (The Bond Market Association), Without SPV, originators cannot separate mortgage debt from other originators' financial assets [33]. Debt sales including the benefits and risks attached to them should have a legal basis [46]. The foundation of this law is not easy to build in civil law countries that generally do not recognize trust [47].

Practitioners suggest that developing countries wishing to apply for securitization should first consider the possibility of establishing an SPV and taxation rules that allow for the sale of tax-exempt debt at the time of the transaction. Tax increases only increase transaction costs and make transactions inefficient [28]. In addition, it is also important to know the form of the SPV's constitution that could be developed based on the sister country of the country concerned, for example the legal system in Argentina accepts trusts as a form of SPV, while in Chilie, it accepts SPVs in the form of corporations [33].

The most common securitization transaction is pay-through. In pay-through transactions, SPVs are typically structured as tax-exempt entities. Failure to achieve tax neutrality can result in double taxation, first on SPV founder sponsorship income and second on distribution of SPV issued effects. Double taxation, of course, makes the transaction inefficient. If the SPV is a corporation, then the minimum tax imposed on the corporation will be calculated from the difference between the balance sheet of the asset and the bond coupon, usually the two components designed to have the smallest difference. If the SPV is a trust, then the SPV's activities should be restricted from investing and only securing the assets that the trust objects to (beneficiaries) [39]. Investors' interest in investing in pay-through bonds in particular: Sister Law that does not open the SPV business body in the form of trust; Lack of transparency in information for efficient transactions; Poor law enforcement [40].

\section{Inefficient Transaction and Cost Savings}

The important thing is that there is a regulation that allows for the most efficient and cost-effective transactions, through the formation of a trust-based SPV, with remote bankruptcy status. Securities offer investors the best quality asset based on a transaction structure designed to protect investors from the potential impact of originators. To ensure that financial assets are protected against bankruptcy, the assets must be removed from the originator balance sheet and placed on the SPV balance sheet. The use of SPVs can reduce the cost of funds because the originator can extract financial assets from their fund so that the financial capacity of the company increases [39].

The duty of the SPV is to buy the financial assets of the originator and issue the debt obligations of the mortgage Financial assets are intended to have a stable cash flow as a source of principal and interest payments to investors. Debt collection in large quantities, usually greater than the value of published effects, is to ensure that the risk of failure to pay has been diversified [48]. The sale of mortgage assets in the form of mortgage debt to the SPV must meet the conditions of the sale with the intention of isolating assets sold from the originating bankruptcy trustee [49]. After making a purchase, the SPV will issue paythrough bonds. This structure can provide the investor with the luxury of investing in a set of assets managed by the SPV, for the benefit of the investor and the investor is also unaffected if the quality of the originator-owned asset deteriorates. In contrast to corporate bonds, for investors, the security of investing in mortgage bonds does not depend on the financial ability of the issuer of mortgage bonds (in this case the SPV), but rather on the quality of the asset that is the basis of the issuance of the effect referred to in Elgueta, G. R [49]. as users and managers, not just acceptors, to be returned to the transferor [50].

In the past, known as 'use upon use,' that was to sell to A, to be managed by B and C. In the wake of The Statue of Uses, B was the sole proprietor of the land, while $\mathrm{A}$ and $\mathrm{C}$ did not own any. Later, in the middle of the XV1 century, the court began to introduce 'The second use' and understood that B had a legal title to the land and that $\mathrm{C}$ had an equitable title as a trust subject to equity so that C's position as 'second use' was unlawful and second use is better known as trust [51]. Thus trust is a 'use' in a new form, hence it is known as 2 ownership, legal title and equitable title [50]. Transferee being a full legal owner of the trust property and its obligation to manage the trust property for the benefit of the transferor is a moral obligation only, since the transferor under the common law has no right to the trust property. On the other hand, according to equity, even if the transferee is a legal owner, the ownership is for the benefit of the transferor only. With equity, the transferor is protected against poor 
transferee dues. Finally, the trustee has legal ownership and the beneficiary has equitable ownership [52].

In trust is a relationship of trust which is the party that requires the trust (settlor) and the person who holds and manages the trust assets (trustee) as well as the party receiving the trust assets (beneficiary). Components of trust under common law: (a) Separation of ownership from trust assets. (b) The Trustee holds and manages the trust assets. (c) Benefit and purpose. (d) The existence of a judiciary overseeing the exercise of trustee rights [53].

Common law trusts are of two types, private trusts and public trusts (charitable trusts). The most widely used private trusts are business trusts. Private trusts are often used for the benefit of an individual / group of people, while public trusts are for the public good as used in education [52]. Trusts discussed here are business trusts, in effect, the trustee receives the surrender of trust assets and is managed for the benefit of beneficiaries [54].

Contributions of trust to the financial sector are: (a) Able to facilitate the separation and placement of assets into a group of assets so that they can be used separately for more than one lender. It thus protects trust assets from claims filed by private lenders from trustees [52]. (b) Cost efficiency, as separate assets are easier to evaluate by rating agencies and investors. (d) Protect the investor as a party to the benefit of the trust assets that have been separated from the originator's assets.

It is thus not affected if the originator drops [55]. Some provisions resembling trust include fiducie, fiducia cum amico and bewind. The civil law system already recognized the concept of fiducie as Roman legal inheritance. Fiducie involves the transfer of assets to one party having a legal title, in the interests of the other. Although resembling a trust, the beneficiary has the right to the person and to claim his rights, depending on the discretion of the judge. Later in 2007, the French Parliament introduced the fiduciary provisions of Article 2011 Chapter 14 French Civil Code.

Settlor assigns all or part of the assets, rights or effects to the fiduciary (trustee) to be managed separately from his personal property, acting in the interests of the beneficiaries, or settlor, or himself [56]. The ownership of the asset is transferred and included in collection of assets (fiduciary's patromony). With the separation of assets, lenders from private settlements or lenders from private fiduciaries do not have access to trust assets in fiduciary patrimony [57].

Further, fiducia cum amico, known in the Netherlands, is the transfer of ownership of an asset by one (transferor) to another (trustee), with the purpose of managing the asset for the benefit of the beneficiary. The party receiving the asset is bound to manage the asset to the best of its ability Gretton, G. L [58]. Trustee (fiduciarius) is also a legal owner who owns the property to manage the assets. However, all claims made by the beneficiary to the trustee are solely in person, meaning that the third party is not aware of such rights. Assets are not kept separately as they are part of the asset that the transferor can claim and the beneficiary has no preference. In the case of fiduciarius of conduct, the beneficiary's position is much weaker than that of the beneficiary in Common Law Loughlin, P. J [59].

Then bewind, is a principle resembling a trust known in the Netherlands. In the bewind, the transferor transfers the asset to the bewind voerder who has the exclusive right to manage the asset for the benefit of the beneficiaries. As with the trust, the sailor separates ownership of the asset. But in the bewind, it is not the bewindvoerder who owns the assets, but the beneficiaries. However, it is not possible for the beneficiary to deal directly with the trust assets as the management rights rest with the bewindvoerder. In the case of beneficiaries' personal bankruptcy, the lender may claim the assets managed by the bewindvoerder, so there is no protection against the beneficiaries. In the case of a bankruptcy trustee, the creditor's legal position of bewindvoerder is weak because the trust assets are owned by the beneficiary. Therefore, bewind cannot be said to be common law trust. Separation of trust assets is an essential element of common law trust, so assets are isolated. The separation was not found in the bewind, as the bewindvoerder had the exclusive right to manage the trusts of assets while the ownership rights were in the bewind beneficiary [60].

The concept of trust in the past is not known in the civil law system, but more and more civil law countries are already using it to support economic activity. Securities transactions using SPVs in the form of common law trusts can be found in several civil law countries such as Argentina, South Africa, Korea.

\section{REFERENCES}

1. Doling, J., Vandenberg, P., \& Tolentino, J. (2013). Housing and Housing Finance-A Review of the Links to Economic Development and Poverty Reduction. Asian Development Bank Economics Working Paper Series, (362).

2. Renaud, B. (1999). The financing of social housing in integrating financial markets: a view from developing countries. Urban Studies, 36(4), 755-773.

3. Parvathamma, C. (1987). Housing, Rural Poor, and Their Living Conditions. Gyan Publishing House.

4. Habitat, U. N. (2013). Huambo Land Readjustment. 
5. Weiss, M. A. (1991). The politics of real estate cycles. Business and Economic History, 127-135.

6. Sellon, G., Roley, V., \& VanNahmen, D. (1988). The securitization of housing finance. Economic Review, 73(7), 3-20.

7. Hirsch Jr, F. A. (2008). The evolution of a suitability standard in the mortgage lending industry: the subprime meltdown fuels the fires of change. NC Banking Inst, 12, 21.

8. Lea, M. J. (1993). Indonesian Secondary Mortgage Market Study. Urban Institute.

9. Lea, M. J., Pollock, A. J., \& Rosengard, J. K. (1997). The Creation of a Secondary Mortgage Facility in Indonesia. Housing Finance International, 12, 24-29.

10. Chiquier, L., Hassler, O., \& Lea, M. J. (2004). Mortgage securities in emerging markets (Vol. 3370). World Bank Publications.

11. Sheng, A. (1997). Housing finance and Asian financial markets: Cinderella coming to the ball. Housing finance international, 12, 3-10.

12. Lejot, P., Arner, D., \& Schou-Zibell, L. (2008). Securitization in East Asia (No. 12). ADB Working Paper Series on Regional Economic Integration.

13. Jaffee, D. M. (1999). Strategies to develop mortgage markets in transition economies. The World Bank.

14. Eldin, Z. B., Mohieldin, M., \& Nasr, S. (2004, September). Prospects of Mortgage Markets in MENA Countries: An Analysis of Financial, Legal and Institutional Aspects with Emphasis on the Egyptian Case Study. Economic Research Forum.

15. Diamond Jr, D. B. (1997). The Promises and Perils of Interest Rate Subsidies: A Survey of Eight Selected Programs. USAID.

16. Clark, C. (2006). Economic Justice and Welfare Reform: Was Welfare Reform an Example of Prudential Judgment in Public Policy. U. St. Thomas LJ, 4, 1.

17. Carmichael, J., \& Pomerleano, M. (2002). Development and Regulation of Non-Bank Financial Institutions. The World Bank.

18. Posner, R. A. (1977). Economic analysis of law, 2nd and 3rd edns.

19. Hardin, R. (1992). The morality of law and economics. Law and Philosophy, 11(4), 331-384.

20. Kerkmeester, H. (2000). 0400 Methodology: general. In Encyclopedia of law and economics: the history and methodology of law and economics/Geest, de, Gerrit [edit.], 1, 383-401.

21. Nicita, A., \& Pagano, U. (2008). Law and economics in retrospect. Brousseau E., Glachant M. New Institutional Economics. A Guidebook, 409-424.

22. Claus, I., Veronica, J., \& Jera, B. (2004). Financial systems and economic growth: An evaluation framework for policy (No. 04/17). New Zealand Treasury.
23. Cheung, S. Y., \& Chan, B. Y. (2002). Bond Markets in the Pacific Rim: Development, Market Structure and Relevant Issues in Fixed Income Securities Markets. Asia-Pacific Development Journal, 9(1), 1-21.

24. Shenker, J. C., \& Colletta, A. J. (1990). Asset securitization: Evolution, current issues and new frontiers. Tex. L. Rev., 69, 1369.

25. Riddiough, T. J. (2011). Can Securitization Work? Economic, Structural, and Policy Considerations. The Journal of Portfolio Management, 37(5), 24 38.

26. Hill, C. A. (1997). Latin American securitization: The case of the disappearing political risk. Va. J. Int'l L., 38, 293.

27. Arner, D. (2002). Emerging Market Economics and Government Promotion of Securitization. Duke J. Comp. \& Int'l L., 12, 505.

28. Alles, M. L. (2001). Asset Securitization and Structured Financing: Future Prospects and Challenges for Countries in Emerging Markets (No. 1-147). International Monetary Fund.

29. Plank, T. E. (2010). Crisis in the Mortgage Finance Market: The Nature of the Mortgage Loan and Regulatory Reform. Transactions: Tenn. J. Bus. L., 12, 135.

30. Schinasi, M. G. J., \& Smith, T. T. (1998). FixedIncome Markets in the United States, Europe, and Japan-Some Lessons for Emerging Markets (EPub) (No. 98-173). International Monetary Fund.

31. Laeven, M. L. (2014). The development of local capital markets: rationale and challenges (No. 14234). International Monetary Fund.

32. Yun-Hwan, K. (1999). Creating Long-term Mortgage-backed Bond Markets in Asian Developing Economies-A Post-crisis Reform Agenda. ADB, EDRC Briefing Notes, (18).

33. Barbour, D., Norton, J., \& Slover, T. (1997). Asset Securitisation in Emerging Market Economies: Fundamental Considerations. YB Int'l Fin. \& Econ. L., 2, 281.

34. Frankel, T. (1997). Cross-border securitization: Without law, but not lawless. Duke J. Comp. \& Int'l L., 8, 255.

35. Cordato, R. E. (1980). The austrian theory of efficiency and the role of government. The Journal of Libertarian Studies, 4(4), 393-403.

36. Solomon, D. (2012). The rise of a giant: Securitization and the global financial crisis. Am. Bus. LJ, 49, 859.

37. Haddad, C. A. (1999). The securitization of assets in Mexico. US-Mex. LJ, 7, 141.

38. Dolan, P. D., \& Davis, C. V. (2000). Securitizations: Legal and Regulatory Issues. Law Journal Press.

39. Gorton, G. B., \& Souleles, N. S. (2007). Special purpose vehicles and securitization. In The risks of financial institutions (pp. 549-602). University of Chicago Press. 
40. Dvorak, Y. A. (2001). Transplanting Asset Securitization: Is the Grass Green Enough on the Other Side. Hous. L. Rev., 38, 541.

41. Elgueta, G. R. (2009). Divergences and Convergences of Common Law and Civil Law Traditions on Asset Partitioning: A Functional Analysis. U. Pa. J. Bus. L., 12, 517.

42. Janger, E. J. (2001). Muddy Rules for Securitizations. Fordham J. Corp. \& Fin. L., 7, 301.

43. Schwarcz, S. L. (2002). The universal language of international securitization. Duke J. Comp. \& Int'l L., 12, 285.

44. Committee on the Global Financial System. (2006). Housing finance in the global financial market. Bank for International Settlements.

45. Langbein, J. H. (1997). The secret life of the trust: the trust as an instrument of commerce. Yale Lj, 107, 165.

46. Kothari, V. (2006). Securitization. The Financial Instrument of the Future, Singapur.

47. Kanda, H. (1997). Securitization in Japan. Duke J. Comp. \& Int'l L., 8, 359.

48. Klee, K. N., \& Butler, B. C. (2002). Asset-backed securitization, special purpose vehicles and other securitization issues. Uniform Commercial Code Law Journal, 35(2), 23-68.

49. Richards, D. A. (1987). Gradable and Tradable": The Securitization of Commercial Real Estate Mortgages. Real Est. LJ, 16, 99-110.

50. Gruning, D. W. (1982). Reception of the Trust in Louisiana: The Case of Reynolds v. Reynolds. Tul. L. Rev., 57, 89-93.
51. Pettit, P. H. (2012). Equity and the Law of Trusts. Oxford University Press.

52. Hansmann, H., \& Mattei, U. (1998). The functions of trust law: a comparative legal and economic analysis. NYUL Rev., 73, 434.

53. Alexander, G. S. (2012). The dilution of the trust.

54. Ho, N. P. (2012). A tale of two cities: Business trust listings and capital markets in Singapore and Hong Kong. J. Int'l Bus. \& L., 11, 311.

55. Figueroa, D. (2007). Civil Trusts in Latin America: Is the Lack of Trusts an Impediment for Expanding Business Opportunities in Latin America. Ariz. J. Int'l \& Comp. L., 24, 701.

56. Forti, V. (2011). Comparing American trust and French fiducie. The Columbia journal of european law online, 17, 28.

57. Koessler, J. (2012). Is there room for the trust in a Civil law system? The French and Italian perspectives. The French and Italian Perspectives.

58. Gretton, G. L. (2000). Trusts without equity. International \& Comparative Law Quarterly, 49(3), 599-620.

59. Loughlin, P. J. (2008). The domestication of the trust: bridging the gap between common law and civil law [interaktyvus]. [žiūrèta 2010-11-02].

60. Donovan Waters. (2004). The Future of Trust from a Worldwide Perspective, Journal of International Trust and Corporate Planning, 11(4): 229. Lihat Gretton, Trust Without Equity, 603. 